\title{
Special Issues in the Australasian Accounting, Business and Finance Journal 2018 and 2019
}

\section{Ciorstan Smark ${ }^{1}$ and Monir Mir ${ }^{2}$}

Does a long Audit relationship lead to less objective auditing? Does how we use words or numbers influence the perception of risk taken from our accounting reports by users of those reports? In the mould (mold) industry in Portugal, does the level of export intensity influence capital structure? What sort of Special Issues does AABFJ choose to publish? These questions are amongst those discussed in this issue of the Australasian Accounting, Business and Finance Journal.

In this issue of AABFJ, Buntara and Adhariani (2019) deal with auditor rotation in Indonesia and the lens of the comfort perspective as it relates to auditor rotation. Also relevant to auditing, Zhang, De Zoysa and Cortese (2019) deals with issues arising from whether uncertainty is best expressed in numerical or linguistic terms and how the diversity in perception of risk may be reduced so that financial statements can be used (and understood) more consistently. Hashim, Ahmed and Huey (2019) have examined board diversity beyond just gender and its relation to earnings quality.

Pecking order and trade-off theory are used by Lisboa (2019) to explain capital structure decisions made by Portuguese mould manufacturers. Aspects of the fraud triangle and other methods are used to consider detecting fraud in Indonesian companies by Fitri, Syukur and Justisa (2019). Wattankul et al. (2019) contribute to the issue with a technical note of relevance to Thailand's policymakers in terms of Thai export policy. Alabdullah (2019) rounds out the issue by examining management accounting techniques used in Jordanian service companies.

As Editors, we have been asked how we decide which special issues to proceed with in AABFJ. To answer this, we refer to the 2018 and 2019 special issues that were chosen by AABFJ. The 2019 special issue was Women in Business In India. As a journal which tries to balance articles from developing countries and developed countries, and qualitative and quantitative articles. Indian women have made enormous contributions in many fields of endeavour. In terms of workplace equality, they face many challenges as do women from many countries. That is worthy of a special issue. Again, diversity and the importance of the topics are of key importance, now onto the specifics of the articles selected for our special issue in 2019 and 2018.

In the Women in Business in India special issue, some of the articles were based on board composition (Singh, Singhania, Shubham \& Sardana, 2019; Charumathi, \& Rahman, 2019). Other articles were more diverse and focussed on social empowerment for women involved in a self-help credit program (Kapoor, 2019) and on Indian women's role in financial planning (Aggarwal \& Singh, 2019). This latter topic was also raised in Sharma and Kota (2019).

The very real challenges faced by Indian businesswomen and other female employees were explored in Srivastava and Cheema (2019) as was the potential to lessen these challenges. Some overlap in terms of challenges for women in India was relayed in Khattar (2019) in the context of

\footnotetext{
${ }^{1}$ University of Wollongong, Australia

${ }^{2}$ University of Canberra, Australia
} 
Indian women in Medicine and the very important role that they have played in terms of not only the profession but its accessibility and relevance to women.

The 2018 special issue, 'The Impact of Regulations and Technology on the Business Environment in India' related to some of our key trends of interest, changes in technology and regulation. The context of the conference from which the 2018 special issue articles were selected is given in Kota (2018). On the technology front, Sharma, Kanojia, and Gupta (2018) analyses shareholder and company secretary reactions to a change in the Indian Companies Act to allow electronic voting at AGMs. Charumathi and Padmaja (2018) explore the relationship between advances in technology and CSR disclosures of Maharatna companies in India. Aspects of technological innovation are also raised in Goel and Singh (2018). Themes of changes in regulation are also strong in this article

The changes in technology in India are also explored in the other articles appearing in this special issue. Lawania and Kapoor (2018) investigate the interesting "Swachh Bharat Abhiyan (SBA)" legislation which encourages corporates and government to cooperate in programs and developments which are good for environmental sustainability. Also relating to Indian Government monetary and investment policy is Misra (2018) and Goel and Singh (2018) which evaluate the outcomes from India's 1990 economic reforms and the relation between Inflation, Money Supply and BSE (Bombay Stock Exchange) share prices respectively. Also studying an interesting reform is Anoop, Parab and Reddy (2018) evaluating the 2016 policy choice to eliminate the Rs. 500 and Rs. 1000 notes in order to lessen corruption. Varma, Singh, and Munjal (2018) looked at a 1998 change in legislation changing share buybacks and the influence of this change (particularly post 2004) on Indian corporate structure and takeover activity. Finally, Murthy and Gambhir (2018) explored the pollution haven hypothesis $(\mathrm{PHH})$ as it relates to India.

We hope that this review has given readers and potential future special issue guest editors some insight into AABFJspecial issues. Next year, in 2020, special issues in the area of the environment and of Asian business are scheduled. Again, the articles are selected with an eye to diversity and the importance of the questions explored.

\section{References}

Aggarwal, Nikunj and Singh, Harjit, Women and Wealth: Financial Propinquity to Business Success, Australasian Accounting, Business and Finance Journal, 13(2), 2019, 69-87. doi:10.14453/aabfj.v13i2.5

Alabdullah, Tariq Tawfeeq Yousif, Management Accounting and Service Companies' Performance: Research in Emerging Economies, Australasian Accounting, Business and Finance Journal, 13(4), 2019, 100-118. doi:10.14453/aabfj.v13i4.8

Anoop, Patil; Parab, Narayan; and Reddy, Y. V., Analyzing the Impact of Demonetization on the Indian Stock Market: Sectoral Evidence using GARCH Model, Australasian Accounting, Business and Finance Journal, 12(2), 2018, 104-116. doi:10.14453/aabfj.v12i2.7

Buntara, Albert Agusto and Adhariani, Desi, Audit Tenure and Audit Quality: the Renewal Sense of Comfort?, Australasian Accounting, Business and Finance Journal, 13(4), 2019, 46-62. doi:10.14453/aabfj.v13i4.4

Charumathi, B. and Padmaja, Gaddam, The Impact of Regulations and Technology on Corporate Social Responsibility Disclosures - Evidence from Maharatna Central Public Sector Enterprises in India, Australasian Accounting, Business and Finance Journal, 12(2), 2018, 5-28. doi:10.14453/aabfj.v12i2.2

Charumathi, B. and Rahman, Habeebu, Do Women on Boards Influence Climate Change Disclosures to CDP? - Evidence from Large Indian Companies, Australasian Accounting, Business and Finance Journal, 13(2), 2019, 5-31. doi:10.14453/aabfj.v13i2.2

Fitri, Fauziah Aida; Syukur, Muhammad; and Justisa, Gita, Do The Fraud Triangle Components Motivate Fraud In Indonesia?, Australasian Accounting, Business and Finance Journal, 13(4), 2019, 63-72. doi:10.14453/aabfj.v13i4.5 
Goel, Nisha and Singh, Gurinder, The Role of Technology and Regulations in Capital Flow to India, Australasian Accounting, Business and Finance Journal, 12(2), 2018, 87-103. doi:10.14453/aabfj.v12i2.6

Hashim, Fathyah; Ahmed, Essia Ries; and Huey, Yeo Min, Board Diversity and Earning Quality: Examining the Role of Internal Audit as a Moderator, Australasian Accounting, Business and Finance Journal, 13(4), 2019, 73-91. doi:10.14453/aabfj.v13i4.6

Kapoor, Shikha, Entrepreneurship for Economic and Social Empowerment of Women: A Case Study of a Self Help Credit Program in Nithari Village, Noida, India, Australasian Accounting, Business and Finance Journal, 13(2), 2019, 123-142. doi:10.14453/aabfj.v13i2.8

Khattar, Sharad, Women in Modern Medicine in India: Progression, Contribution, Challenges and Empowerment, Australasian Accounting, Business and Finance Journal, 13(2), 2019, 88106. doi:10.14453/aabfj.v13i2.6

Kota, Hima Bindu, Editorial: The Impact of Regulations and Technology on the Business Environment in India, Australasian Accounting, Business and Finance Journal, 12(2), 2018, 1-4. doi:10.14453/aabfj.v12i2.1

Lawania, Beena D. and Kapoor, Shikha, Leveraging Corporate Social Responsibility for the Advancement of Development Goals in India: Sanitation and Cleanliness Movement in India, Australasian Accounting, Business and Finance Journal, 12(2), 2018, 46-70. doi:10.14453/aabfj.v12i2.4

Lisboa, Inês, Capital Structure Choices and Exports: the Case of the Portuguese Mold Industry, Australasian Accounting, Business and Finance Journal, 13(4), 2019, 23-45. doi:10.14453/aabfj.v13i4.3

Misra, Pooja, An Investigation of the Macroeconomic Factors Affecting the Indian Stock Market, Australasian Accounting, Business and Finance Journal, 12(2), 2018, 71-86. doi:10.14453/aabfj.v12i2.5

Murthy, K. V. Bhanu and Gambhir, Sakshi, Analyzing Environmental Kuznets Curve and Pollution Haven Hypothesis in India in the Context of Domestic and Global Policy Change, Australasian Accounting, Business and Finance Journal, 12(2), 2018, 134-156. doi:10.14453/aabfj.v12i2.9

Sharma, J. P.; Kanojia, Sunaina; and Gupta, Shasta, An Empirical Evaluation of Legislative Reforms for E-Corporate Governance in Indian Companies, Australasian Accounting, Business and Finance Journal, 12(2), 2018, 29-45. doi:10.14453/aabfj.v12i2.3

Sharma, Manish and Kota, Hima Bindu, The Role of Working Women in Investment Decision Making in the Family in India, Australasian Accounting, Business and Finance Journal, 13(3), 2019, 91-110. doi:10.14453/aabfj.v13i3.6

Singh, Amit Kumar; Singhania, Shubham; and Sardana, Varda, Do Women on Boards affect Firm's Financial Performance? Evidence from Indian IPO Firms, Australasian Accounting, Business and Finance Journal, 13(2), 2019, 53-68. doi:10.14453/aabfj.v13i2.4

Srivastava, Ritu and Cheema, Surbhi, How Gender Integration Can Reduce the Income-Inequality Gap, Australasian Accounting, Business and Finance Journal, 13(2), 2019, 32-52. doi:10.14453/aabfj.v13i2.3

Varma, Urvashi; Singh, Harjit; and Munjal, Alka, Corporate Restructuring through Share buybacks: An Indian Experience, Australasian Accounting, Business and Finance Journal, 12(2), 2018, 117-133. doi:10.14453/aabfj.v12i2.8

Wattanakul, Thanet; Nonthapot, Sakkrin; and Watchalaanun, Tanawat, An Analysis of the Competitiveness and Market Expansion of Thailand's Rubber Smoked Sheet Exports - A Technical Note, Australasian Accounting, Business and Finance Journal, 13(4), 2019, 9299. doi:10.14453/aabfj.v13i4.7

Zhang, Yuqian; De Zoysa, Anura; and Cortese, Corinne, Uncertainty Expressions in Accounting: Critical Issues and Recommendations, Australasian Accounting, Business and Finance Journal, 13(4), 2019, 4-22. doi:10.14453/aabfj.v13i4.2 